\title{
Enerǵy and protein value of low glucosinolate or dehulled rapeseed oil-meals and of a sunflower oil-meal in growing pigs
}

\author{
D. BOURDON, J.-J. BAUDET \\ Station de Recherches sur l'Élevage des Porcs, \\ Centre national de Recherches zootechniques, I.N.R.A., \\ 78350 Jouy-en-Josas (France) \\ C.E.T.I.O.M., I74, avenue Victor-Hugo, 75116 Paris
}

A digestibility sudy in growing pigs was carried out by direct measurements according to the substitution method in order to assess the energy and protein value of three types of rapeseed oils-meals and a sunflower oil-meal:

- a low glucosinolate rapeseed meal improved by the genetic way;

- a hormal low erucic acid Primor rapeseed meal;

- a dehulled Primor rapeseed meal;

- a sunflower meal.

The trial involved 36 Large White pigs with a mean live weight of $36.9 \mathrm{~kg}$ distributed into 9 groups of 4 pigs. The energy and protein value of each meal was assessed at two incorporation levels (I 2 and 24 p. Ioo) for the low glucosinolate rapeseed oil-meal (8 and i 6 p. Ioo), for the other meals as compared to a control diet containing only maize. Faecal collection was made during to consecutive days.

Only orie mean estimate was retained from the results for both incorporation levels of each meal: for the normal low glucosinolate Primor rapeseed oil meal, dehulled Primor and sunflower the values expressed in digestible and metabolisable energy in $\mathrm{Kcal} / \mathrm{kg}$ dry matter were 3828 , $3698-2916,2575-3$ 30I, 2693 and 2722,2 I 60, respectively, corresponding to energy and protein apparent digestibility coefficients of $78.7 ; 85.6-6$ I.5;80.0-7I.4;85.8 and $59.4 ; 89.4$

This study showed that for rather similar crude fibre contents ( $13.6 \mathrm{p}$. Ioo) the digestible energy value of low glucosinolate rapeseed oil-meal (o-thio) was improved by 30 p. Ioo as compared to that of the normal Primor rapeseed meal (I $4.6 \mathrm{p}$. roo crude fibre). The dehulling led to a I $6 \mathrm{p}$. Ioo increase of the apparent digestibility of energy and a $7 \mathrm{p}$. Ioo increase of that of protein after a $5.4 \mathrm{p}$. roo reduction of the crude fibre content of the product. The very good digestibility of sunflower protein was confirmed. Moreover, it appeared that the use of genetics to obtain low glucosinolate rapeseed and of a technological treatment (dehulling) were efficient techniques for improving the nutritional value of rapeseed meal in pigs.

\section{Feeding of fattening pigs according to Lehmann's method with skim milk or yoghurt containing lactic acid bacteria alive or dead}

\author{
C. FEVRIER ( $\left.{ }^{1}\right)$, R. DUCLUZEAU $\left({ }^{2}\right)$, L. VASSAL ( $\left.{ }^{(}\right)$ \\ (1) Station de Recherches sur l'Elevage des Porcs \\ (2) Laboratoive d'Écologie Microbienne \\ ${ }^{\left({ }^{3}\right)}$ Laboratoive de Biochimie et Technologie Laitière \\ Centre national de Recherches Zootechniques, I.N.R.A., \\ 78350 Jouy-en-Josas (France)
}

Lehmann's traditional feeding method based on a daily supply of a constant amount of 4 litres of skim milk and of an increasing amount of barley as well as a mineral vitamin mixture was compared to a feeding technique using complete growing-finishing diets theoretically supply- 
ing the same amount of energy and amino acids as the previous regimen for each of both periods. Skim milk was offered either as such or after transformation into yoghurt (Streptococcus thermophilus, C.N.R.Z. I60 and Lactobacillus bulgavicus C.N.R.Z. 369) or after treatment of the yoghurt with hydrogen peroxyde $(0.8 \mathrm{p}$. Ioo) to kill the bacteria. The total flora of skim milk obtained from raw milk was multiplied by ${ }_{5} 5$ and coliform bacteria by 190 after 3 or 4 days of preservation. In the yoghurt, coliform bacteria remained at the same level than that of raw milk, below roo germs $/ \mathrm{ml}$. The yoghurt treatment with hydrogen peroxyde destroyed $99.96 \mathrm{p}$. Ioo of the bacteria. However, these results were only obtained with 3 castrated males and 3 females per group. For the whole fattening period the animal performances were not significantly different in the 4 groups, nor was the carcass quality. Only females showed a slightly higher feed conversion ratio than that of castrated males ( + o.I I) and leaner carcasses. This difference could be due to the fact that minimum levels of nitrogen and amino acids were offered to the castrated males and sub-optimum to the females (especially with the yoghurt).

The faecal flora (q) was not modified by milk or by the treatment of the latter. Only $\mathrm{H}_{2} \mathrm{O}_{2}$ seemed to produce a slight increase in enterobacteria during the first weeks. In stomachal, intestinal and caecal contents little difference was observed in the amount of enterobacteria and lactobacilli whatever the treatment. Only one bifidobacterium was present in the stomach and intestine of pigs receiving milk, whereas it was absent in the yoghurt group and occasional elsewhere. Although the transformation of milk into yoghurt may facilitate its preservation, it does not seem to show a particular advantage for growing pigs.

\title{
Effect of a prolonged feeding of $P$ and Ca deficient diets in growing-finishing pigs
}

\author{
Y. MAURY, M. COLIN \\ Sanders S.A., I7, quai de l'Industrie, 9I20o Athis-Mons (France)
}

This experiment was conducted to study the effect of feeding pigs, from $35 \mathrm{~kg}$ up to slaughter at $90 \mathrm{~kg}$ live-weight, with commercial feeds in which $\mathrm{Ca}$ or $\mathrm{P}$ were lowered.

No significant differences were observed in chemical values of serum $\mathrm{Ca}, \mathrm{P}, \mathrm{Mg}$ and alkaline phosphatase with the lowered $\mathrm{Ca}$ feeds. However, the serum value of the protein content was reduced.

When the level of $\mathrm{P}$ was lowered, the $\mathrm{Ca}$ and alkaline phosphatase serum value increased and the $\mathrm{P}$ serum value decreased. This led to a rise in the Ca/P ratio. The biochemical determination of serum $\mathrm{Ca}, \mathrm{P}, \mathrm{Ca} / \mathrm{P}$ and alkaline phosphatase might be used to evidence a deficiency of $\mathrm{P}$ in the feed.

No lameness or locomotion disturbances were observed during the assay but the bone ash and its $\mathrm{Ca}$ and $\mathrm{P}$ contents were lowered when using the experimental feeds. This trend was more marked with the $\mathrm{P}$ deficient than with the $\mathrm{Ca}$ deficient diets. However, the histological structure did not change.

The daily weight gain and the feed efficiency decreased with the $\mathrm{P}$ or Ca deficiency of the experimental diets. 